\title{
Genetic and Non-genetic Factors Affecting Gestation Length and Calve Birth Weight of Sahiwal- Friesian Frossbred Groups
}

\author{
M.A.I. Talukder ${ }^{1 *}$ and J.M. Panandam ${ }^{2}$ \\ ${ }^{1}$ Bangladesh Livestock Research Institute, Savar, Dhaka-1341 \\ ${ }^{2}$ Department of Animal Science, University Putra Malaysia, \\ 43400 UPM, Serdang, Selangor, Malaysia \\ ${ }^{*}$ Corresponding author:
}

\begin{abstract}
This study focused on the dairy unit at the Ladang Pusat Ternakan Haiwan Ayer Hitam in Johor, Malaysia. Eight crossbreed groups namely M50, M50-1, M50-2, M50-3, M56, M63, M75 and M75-1 were evaluated. Retrospective data on gestation length and calf birth weight were extracted for evaluation of 1346 animals and were analyzed between 1981 and 2001. Effects of breed group, parity, calf sex and age at calving were non significant for GL. Year of birth was only significant $(\mathrm{P}<0.05)$ affected for GL. The GL for the breed groups ranged between 279 - 283 days. The cow breed group $\times$ parity interaction effect was significant $(\mathrm{P}<0.05)$ for $\mathrm{CBW}$. Sire breed group, calf sex and age at calving significantly $(\mathrm{P}<0.05)$ affected the $\mathrm{CBW}$. There was no significant difference in $\mathrm{CBW}$ of the cow breed groups for the first two parities. M50, M50-1, M63 and M75-1 had significantly $(\mathrm{P}<0.05)$ higher $\mathrm{CBW}$ in the third and fourth parity $(26.76-28.98 \mathrm{~kg})$. M50-3 and M56 had significantly $(\mathrm{P}<0.05)$ lower CBW than M50 and M63. M56 had the lowest $(\mathrm{P}<0.05) \mathrm{CBW}$ in the fourth parity $(22.22 \pm 1.24 \mathrm{~kg})$. Individual additive genetic effect, maternal additive genetic effect, individual heterosis and maternal heterosis were non-significant for GL and CBW. Calf sex significantly $(\mathrm{P}<0.01)$ affected the $\mathrm{CBW}$ in all breed groups except M56 and M63. Male calves weighed significantly $(\mathrm{P}<0.01)$ heavier than female calves in the earlier breed group. Calf mortality ranged between $3.49-$ 7.27\%. The highest calf mortality at birth was observed in M75 (7.27\%) followed by M50-3 $(6.8 \%)$ and M75-1 (5.66\%). The lowest mortality was observed in M50-1. M50, M50-1, M63 and M75-1 had better performance on CBW. Higher Friesian grades calf mortality rate was higher than lower Friesian grades. The non genetic factor year of birth only affected GL, but most of the genetic and non genetic factors significantly $(\mathrm{P}<0.05)$ affected the $\mathrm{CBW}$.
\end{abstract}

Keywords: Crossbreed groups, dairy, calve birth \& mortality, weight

\section{Introduction}

The dairy market in Malaysia is mainly dependent on imported milk and milk products as the country produces only $4.5 \%$ only her requirement (DVS, 1998). In order to realise these targets, the government embarked on a crossbreeding programme involving the Sahiwal and Friesian dairy cattle breeds (Osman, 1993). The Department of Veterinary Services imported a large number of Sahiwal $\times$ Friesian crossbreeds and purebreds Friesians from Australia and New Zealand in 1978 (Sivarajasingam et al., 1982). The crossbreeding programme aimed to grade up crossbreeds by continual crossing with Friesian. As a result crossbreeds with 50, 56.25, 62.5 and $75 \%$ Friesian genes have been produced. However, due to improving different grades, other characteristics such as adaptability, fertility, resistance to diseases, and calving are also affected. Gestation period is the important measure of reproductive efficiency of animals as they contribute to the length of calving interval since, the variation of gestation period is very small. Gestation length varies among breeds with Bos indicus females tending to have longer gestation lengths (290- 300 days) than Bos taurus females (generally, 280- 285 days) (Velefilho et al., 
1986; Randel, 1990). There exists in the life cycle of cattle, critical stages when mortality hits a peak and one such period is at birth and a few days after. Three major causes of mortality at this stage are week calf at birth, poor maternal influence and unfavorable environment. Breeding and selection for heavier calf birth weight, which is assumed to be also healthier, will greatly cut down early losses. Selection for growth and moderate birth weights could be effective in beef cattle breeding (Bourdon and Brinks, 1982). These will help present early calf mortality and occurrence of dystokia cases. Heavy calves at birth result in calf survival, growth (Leibholz, 1973) and milk yield (Chew et al., 1981). Several scientists also indicated that the dams that gave heavier calves at birth also produced about 10\% more milk (Chew et al., 1981 and Sivarajasingam and Mukherjee, 1982) than dams that gave lighter calves. The study was carried out to compare genetic and non genetic factors affecting gestation length and calve birth weight of some of the above Sahiwal-Friesian crossbreed groups.

\section{Materials and Methods}

The animals referred to in this study are those, which were in the research farm of the Ladang Pusat Ternakan Haiwan at Ayer Hitam, Johor, under the Department of Veterinary Service (DVS), Malaysia. The animals studied in this study are those who reared between the years 1981 to 2001 of that farm. They comprised of Sahiwal - Friesian crossbreed cows of various percentage of Friesian inheritance. Sahiwal $\times$ Friesian $F_{1}$ crosses were imported from Australia and New Zealand as heifers or as calf heifers (Sivarajasingam and Kumar, 1993). Though inter se mating and crossbreeding, using imported semen and that from selected sires, a number of crossbreed groups with Friesian inheritance ranging from $50 \%-75 \%$ were produced.

Eight Sahiwal-Friesian breed groups, namely M50, M50-1, M50-2, M50-3. M56, M63, M75 and $\mathrm{m} 75-1$, were evaluated. The sample sizes of the various breed groups, which represent the experimental stock in this study. The crossbreed groups with sufficient number of females per group $(659,170,173,89,88,54,25$ and 88) were chosen for the study. The crossbreed groups M50 (imported 50\% Sahiwal - 50\% Friesian $\mathrm{F}_{1}$ ), M50-1 (Sahiwal - Friesian $\mathrm{F}_{2}$ ), M50-2 (Sahiwal - Friesian $\mathrm{F}_{3}$ ), M50-3 (Sahiwal Friesian $\mathrm{F}_{4}$ ), M56 (Sahiwal - Friesian crossbreeds with $56 \%$ Friesian genes, produced by inter se mating of the $45.75 \%$ Sahiwal $56.25 \%$ Friesian $\mathrm{BC}_{3}$ ), M63 (Sahiwal - Friesian crossbreeds with $63 \%$ Friesian genes, produced by inter se mating of the $37.5 \%$ Sahiwal $-62.5 \%$ Friesian $\mathrm{BC}_{2}$ ), M75 (25\% Sahiwal - 75\% Friesian $\mathrm{BC}_{1}$ ) and M75-1 (produced by inter se mating of M75).

The length of gestation was calculated as the interval from fertile service to parturition. Calves were weighted soon after parturition. Calf mortality rate was the percentage of the number death among the calf to the number of calves born during the period of study. The management practice was to keep the cows on pasture throughout the day and night, except during milking. The pastures were mainly of Brachiaria decumbens (90\%), Panicum maximum and Paspalm sp. The cows were allowed to graze on pasture at the rate of 1.7 acre /animal. Milking cows were supplied concentrate Palm Karnal Cake (PKC) before milking. Level of feeding was determined on the basis of milk output, approximately $1 \mathrm{~kg}$ concentrate for every $4 \mathrm{~kg}$ of milk produced. The late gestation herds were fed concentrate, molasses, grass, mineral block and dicalcium phosphate (DCP). Supplements were given at the rate of 3 - $5 \mathrm{~kg}$ per head per day. Selenium and vitamin $\mathrm{ADE}$ injection were also given. Before calving the animals were moved to special calving pens.

Data on gestation length and calf birth weight were extracted for evaluation of 1346 animals. Data on these traits were extracted only for the first four parities. The statistical analysis of the data was performed using general linear model (GLM) procedure of the Statistical Analysis System (SAS) for Windows 2000 PC software package. The differences between treatment means were examined using least significant difference (LSD). 
The statistical model assumed for the length of the gestation period was:

$\mathrm{Z}_{\mathrm{ijklm}}=\mu+\mathrm{Y}_{\mathrm{i}}+\mathrm{B}_{\mathrm{j}}+\mathrm{P}_{\mathrm{k}}+(\mathrm{B} \times \mathrm{P})_{\mathrm{jk}}+\mathrm{A}_{\mathrm{l}}+\mathrm{e}_{\mathrm{ijklm}}$

where,

$$
\begin{aligned}
\mathrm{Z}_{\mathrm{ijk} k m}= & \text { gestation period of m-th cow, of } \mathrm{j} \text {-th breed group, } \\
& \mathrm{k} \text {-th parity and } 1 \text {-th age at calving born in the } \mathrm{i} \text {-th year. } \\
\mu & =\text { overall mean length of the gestation period, } \\
\mathrm{Y}_{\mathrm{i}} & =\text { effect of } \mathrm{i} \text {-th year of birth of cow, } \\
\mathrm{B}_{\mathrm{j}} & =\text { effect of } \mathrm{j} \text {-th breed group of cow, } \\
\mathrm{P}_{\mathrm{k}} & =\text { effect of k-th parity, } \\
\mathrm{A}_{\mathrm{l}} & =\text { effect of l-th age at calving, }
\end{aligned}
$$

$(\mathrm{B} \times \mathrm{P})_{\mathrm{jk}}=$ effect of interaction between breed group and parity $\mathrm{e}_{\mathrm{ijklm}}=$ random error, assumed to be normally distributed with mean zero and common variance. The statistical model used for the birth weight of calves was: $Z_{i j k l m n}=\mu+Y_{i}+B_{j}+S_{k}+P_{1}+S_{m}+(B \times S B)_{j k}+(B \times P)_{j l}+(B \times S) j_{j m}+$ $(\mathrm{SB} \times \mathrm{P})_{\mathrm{kl}}+(\mathrm{SB} \times \mathrm{S})_{\mathrm{km}}+(\mathrm{P} \times \mathrm{S})_{\mathrm{lm}}+\mathrm{A}_{\mathrm{n}}+\mathrm{e}_{\mathrm{ijklmn}}$

where, $Z_{\mathrm{ijklmn}}=$ birth weight of the $\mathrm{p}$-th calf $\mathrm{m}$-th sex, born in the $\mathrm{i}$-th year, to the cow of the $\mathrm{j}$-th breed , 1-th parity and n-th age of calving, mated to the bull of the k-th breed group.

$\mu=$ overall mean birth weight;

$Y_{i}=$ effect of i-th year $(1981-1996)$

$\mathrm{B}_{\mathrm{j}}=$ effect of $\mathrm{j}$-th breed group (M50, M50-1, M50-2, M50-3, M56, M63, M75 and M75-1)

$\mathrm{SB}_{\mathrm{k}}=$ effect of $\mathrm{k}$-th sire breed $(50,56,63,69,75$ and $100 \%$ Friesian inheritance)

$\mathrm{P}_{1}=$ effect of 1-th parity ( $1-4$ parity)

$\mathrm{S}_{\mathrm{m}}=$ effect of $\mathrm{m}$-th sex (male and female)

$(\mathrm{B} \times \mathrm{SB})_{\mathrm{jk}},(\mathrm{B} \times \mathrm{P})_{\mathrm{jl}},(\mathrm{B} \times \mathrm{S})_{\mathrm{jm}},=$ effect of two -way interactions between

$(\mathrm{SB} \times \mathrm{P})_{\mathrm{kl}},(\mathrm{SB} \times \mathrm{S})_{\mathrm{km}},(\mathrm{P} \times \mathrm{S})_{\mathrm{lm}}$ independent, discreet variables mentioned above

$$
\mathrm{A}_{\mathrm{n}}=\text { effect of } \mathrm{n} \text {-th age at calving }
$$

$\mathrm{e}_{\mathrm{ijklmnp}}=$ random error, assumed to be normally distributed with mean zero and common variance

\section{Results and Discussions}

\subsection{Gestation Length (GL)}

The two-way interaction effects on GL for the factors considered in the model were non significant (Table 1). Effects of breed group, parity, calf sex and age at calving were non significant. Year of birth had only significant $(\mathrm{P}<0.05)$ effect for GL. The GL for the breed groups ranged between 279 - 283 days (Table 2). Individual additive genetic effect, maternal additive genetic effect, individual heterosis and maternal heterosis were non-significant for GL (Table 4).

\subsection{Calf Birth Weight (CBW)}

The cow breed group $\times$ parity interaction effect was significant $(\mathrm{P}<0.05)$ for $\mathrm{CBW}$ (Table 1).
The other interactions effects considered were non significant. Sire breed group, calf sex and age at calving significantly $(\mathrm{P}<0.05)$ affected the CBW. There was no significant difference in CBW among the cow breed groups for the first two parities (Table 3). M50, M50-1, M50-2, M63 and M75-1 had similar CBW in the third parity (27 - $29 \mathrm{~kg}) . \quad$ M50-3 and M56 had significantly $(\mathrm{P}<0.05)$ lower CBW than M50 and M63. M56 had the lowest $(\mathrm{P}<0.05) \mathrm{CBW}$ in the fourth parity $(22.22 \pm 1.24 \mathrm{~kg})$. $\mathrm{CBW}$ was the lowest in first parity and gradually increased in the third parities. Individual additive genetic effect, maternal additive genetic effect, individual heterosis and maternal heterosis were non-significant for CBW (Table 4) 
Table 1. Analysis of variance of gestation length (GL) (days) and calve birth weight (CBW) (kg).

\begin{tabular}{lllll}
\hline \multirow{2}{*}{$\begin{array}{l}\text { Source of } \\
\text { Variation }\end{array}$} & \multicolumn{2}{c}{ Gestation length } & \multicolumn{2}{c}{ Calf birth weight } \\
\cline { 2 - 5 } & $\mathrm{F}$ & \multicolumn{1}{c}{ MS } & DF & MS \\
\hline YB & 14 & $55.89^{*}$ & 15 & $121.50^{* *}$ \\
BG & 7 & $45.49 \mathrm{~ns}$ & 7 & $49.64 \mathrm{~ns}$ \\
SBG & - & - & 5 & $60.23^{*}$ \\
PA & 3 & $29.11 \mathrm{~ns}$ & 3 & $138.60^{* *}$ \\
CSex & 1 & $3.46 \mathrm{~ns}$ & 1 & $1118.34^{* *}$ \\
BG*PA & 21 & $38.55 \mathrm{~ns}$ & 21 & $43.62^{*}$ \\
BG*CSex & 7 & $13.61 \mathrm{~ns}$ & 7 & $32.31 \mathrm{~ns}$ \\
PA*CSex & 3 & $2.18 \mathrm{~ns}$ & 3 & $18.32 \mathrm{~ns}$ \\
AC & 1 & $0.06 \mathrm{~ns}$ & 1 & $158.50^{* *}$ \\
Error & 2603 & 32.19 & 3382 & 26.27 \\
Corr. Total & 2660 & & 3445 & - \\
$\mathrm{R}^{2}$ & 0.03 & & 0.13 & - \\
\hline
\end{tabular}

$\mathrm{YB}=$ Year of birth, $\mathrm{BG}=$ Breed group, $\mathrm{SBG}=$ Sire breed group $\mathrm{PA}=$ Parity,

Csex $=$ Calve sex, $\mathrm{AC}=$ Age at calving,

* Significant $(\mathrm{P}<0.05)$, ** Significant $(\mathrm{P}<0.01)$

Table 2. Lsmeans ( \pm SE) of gestation length (GL) (days) with respect to breed group and parity.

\begin{tabular}{|c|c|c|c|c|c|}
\hline \multirow{2}{*}{$\begin{array}{l}\text { Breed } \\
\text { Group }\end{array}$} & \multicolumn{5}{|c|}{ Parity } \\
\hline & 1 & 2 & 3 & 4 & Overall \\
\hline M50 & $\begin{array}{c}282.83^{\mathrm{ns}} \pm 0.42 \\
(419)\end{array}$ & $\begin{array}{c}283.18^{\mathrm{abc}} \pm 0.39 \\
(291)\end{array}$ & $\begin{array}{c}282.29^{\text {ns }} \pm 0.49 \\
(194)\end{array}$ & $\begin{array}{c}282.05^{\mathrm{ns}} \pm 0.66 \\
(124)\end{array}$ & $282.59^{\mathrm{ab}} \pm 0.28$ \\
\hline M50-1 & $\begin{array}{c}282.77^{\text {ns }} \pm 0.52 \\
(189)\end{array}$ & $\begin{array}{c}282.05^{\mathrm{a}} \pm 0.48 \\
(175)\end{array}$ & $\begin{array}{c}282.67^{\mathrm{ns}} \pm 0.53 \\
(149)\end{array}$ & $\begin{array}{c}281.58^{\mathrm{ns}} \pm 0.65 \\
(121)\end{array}$ & $282.27^{\mathrm{ab}} \pm 0.31$ \\
\hline M50-2 & $\begin{array}{c}282.79^{\mathrm{ns}} \pm 0.55 \\
(159)\end{array}$ & $\begin{array}{c}283.0^{\mathrm{bc}} \pm 0.51 \\
(149)\end{array}$ & $\begin{array}{c}282.82^{\mathrm{ns}} \pm 0.59 \\
(130)\end{array}$ & $\begin{array}{c}282.70^{\mathrm{ns}} \pm 0.71 \\
(104)\end{array}$ & $282.91^{\mathrm{b}} \pm 0.32$ \\
\hline M50-3 & $\begin{array}{c}283.43^{\mathrm{ns}} \pm 0.76 \\
(84)\end{array}$ & $\begin{array}{c}282.49^{\mathrm{ab}} \pm 0.79 \\
(65)\end{array}$ & $\begin{array}{c}282.06^{\mathrm{ns}} \pm 1.27 \\
(28)\end{array}$ & $\begin{array}{c}280.40^{\mathrm{ns}} \pm 1.94 \\
(10)\end{array}$ & $282.09^{\mathrm{ab}} \pm 0.66$ \\
\hline M56 & $\begin{array}{c}282.41^{\mathrm{ns}} \pm 0.75 \\
(54)\end{array}$ & $\begin{array}{c}282.98^{a b c} \pm 0.82 \\
(59)\end{array}$ & $\begin{array}{c}281.61^{\mathrm{ns}} \pm 1.02 \\
(35)\end{array}$ & $\begin{array}{c}279.12^{\mathrm{ns}} \pm 1.95 \\
(10)\end{array}$ & $281.53^{\mathrm{a}} \pm 0.66$ \\
\hline M63 & $\begin{array}{c}282.27^{\mathrm{ns}} \pm 1.24 \\
(32)\end{array}$ & $\begin{array}{c}286.15^{c} \pm 1.58 \\
(15)\end{array}$ & $\begin{array}{c}282.60^{\mathrm{ns}} \pm 1.92 \\
(10)\end{array}$ & $\begin{array}{c}279.02^{\mathrm{ns}} \pm 2.35 \\
(10)\end{array}$ & $282.51^{\mathrm{ab}} \pm 0.94$ \\
\hline M75 & $\begin{array}{c}282.08^{\mathrm{ns}} \pm 1.94 \\
\text { (9) }\end{array}$ & $\begin{array}{c}275.18^{\mathrm{d}} \pm 2.58 \\
(15)\end{array}$ & - & - & $279.13^{\mathrm{a}} \pm 1.99$ \\
\hline M75-1 & $\begin{array}{c}283.58^{\mathrm{a}} \pm 0.78 \\
(72)\end{array}$ & $\begin{array}{c}281.85^{\mathrm{a}} \pm 0.92 \\
(44)\end{array}$ & $\begin{array}{c}284.50^{\mathrm{ns}} \pm 1.21 \\
(24)\end{array}$ & $\begin{array}{c}282.25^{\mathrm{a}} \pm 1.69 \\
(13)\end{array}$ & $283.04^{\mathrm{b}} \pm 0.64$ \\
\hline Overall & $\begin{array}{c}282.77^{\mathrm{ns}} \pm 0.45 \\
(1049)\end{array}$ & $\begin{array}{c}282.15^{\mathrm{ns}} \pm 0.46 \\
(803)\end{array}$ & $\begin{array}{c}282.09^{\mathrm{ns}} \pm 0.68 \\
(572)\end{array}$ & $\begin{array}{c}281.03^{\mathrm{ns}} \pm 0.97 \\
(388)\end{array}$ & \\
\hline
\end{tabular}

For a particular parity (column), means that do not share any of the superscripts differ significantly $(\mathrm{P}<0.05)$.

Values in the parenthesis give the sample size.

- excluded due small sample size. 


\subsection{Calf Sex}

Calf sex significantly $(\mathrm{P}<0.01)$ influenced the CBW in all breed groups except M56 and M63 (Table 5). Male calves weighed significantly $(\mathrm{P}<0.01)$ heavier than female calves in the earlier breed group.

\subsection{Calf Mortality}

The percentages of calf death for the eight cow breed groups are presented in Table 5. Calf mortality ranged between $3.49-7.27 \%$. The highest calf mortality at birth was observed in M75 (7.27\%), followed by M50-3 (6.8\%) and M75-1 (5.66\%). The lowest mortality was observed in M50-1(3.49).

Effects of breed group, parity, calf sex and age at calving and their interaction effects on GL were non significant. The mean of GL ranged from 279 - 283 days. Year of birth was the only significant $(\mathrm{P}<0.05)$ factor influencing GL. Yearly difference might have been due to management, nutrition and environmental factors that fluctuated over the years.

GL for various Sahiwal - Friesian grades have been reported to range between 270 to 284 days (Singh et al., 1980; Majid et al., 1996). Genetic group effect has also been observed to be non significant in different grades of other crossbreed dairy cows (Rajan et al., 1981; Roy et al., 1985; Islam and Bhuiyan, 1997).

Year of birth and parity has a significant effect $(\mathrm{P}<0.01)$ on CBW. Similar results also found in Native cattle ( Dev and Talukder, 2006). The interaction effect of cow breed group $\times$ parity was significant $(\mathrm{P}<0.1)$ for $\mathrm{CBW}$. There was non significant difference in $\mathrm{CBW}$ among the breed groups for the first two parities. M50-3 and M56 had significantly $(\mathrm{P}<0.05)$ lower $\mathrm{CBW}$ than M50 in the third parity. M56 had the lowest CBW in the fourth parity.

Table 3. Lsmeans $( \pm \mathrm{SE})$ of calve birth weight $(\mathrm{CBW})(\mathrm{kg})$ with respect to breed group and parity of the cow.

\begin{tabular}{|c|c|c|c|c|}
\hline \multirow{2}{*}{$\begin{array}{l}\text { Breed } \\
\text { Group }\end{array}$} & \multicolumn{4}{|c|}{ Parity } \\
\hline & 1 & 2 & 3 & 4 \\
\hline M50 & $\begin{array}{c}24.62^{\mathrm{ns}} \pm 0.73 \\
(659)\end{array}$ & $\begin{array}{c}26.85^{\text {ns }} \pm 0.72 \\
(390)\end{array}$ & $\begin{array}{c}27.48^{\mathrm{a}} \pm 0.76 \\
(250)\end{array}$ & $\begin{array}{c}27.62^{a} \pm 0.83 \\
(163)\end{array}$ \\
\hline M50-1 & $\begin{array}{c}24.42^{\mathrm{ns}} \pm 0.79 \\
(170)\end{array}$ & $\begin{array}{c}26.86^{\mathrm{ns}} \pm 0.78 \\
(170)\end{array}$ & $\begin{array}{c}26.97^{\mathrm{ab}} \pm 0.81 \\
(148)\end{array}$ & $\begin{array}{c}27.20^{\mathrm{a}} \pm 0.87 \\
(129)\end{array}$ \\
\hline M50-2 & $\begin{array}{c}24.66^{\mathrm{ns}} \pm 0.79 \\
(173)\end{array}$ & $\begin{array}{c}26.80^{\mathrm{ns}} \pm 0.78 \\
(164)\end{array}$ & $\begin{array}{c}26.76^{\mathrm{ab}} \pm 0.81 \\
\quad(139)\end{array}$ & $\begin{array}{c}25.73^{\mathrm{b}} \pm 0.87 \\
(131)\end{array}$ \\
\hline M50-3 & $\begin{array}{c}25.16^{\mathrm{ns}} \pm 0.89 \\
(89)\end{array}$ & $\begin{array}{c}26.84^{\mathrm{ns}} \pm 0.89 \\
(84)\end{array}$ & $\begin{array}{c}25.54^{\mathrm{b}} \pm 0.99 \\
(53)\end{array}$ & $\begin{array}{c}26.37^{\mathrm{ab}} \pm 1.26 \\
(25\end{array}$ \\
\hline M56 & $\begin{array}{c}23.18^{\mathrm{ns}} \pm 0.85 \\
(88)\end{array}$ & $\begin{array}{c}24.89^{\mathrm{ns}} \pm 0.87 \\
(76)\end{array}$ & $\begin{array}{c}24.63^{\mathrm{b}} \pm 1.02 \\
(52)\end{array}$ & $\begin{array}{c}22.22^{\mathrm{c}} \pm 1.24 \\
(28)\end{array}$ \\
\hline M63 & $\begin{array}{c}25.30^{\mathrm{ns}} \pm 1.18 \\
(54)\end{array}$ & $\begin{array}{c}26.32^{\mathrm{ns}} \pm 1.25 \\
(36)\end{array}$ & $\begin{array}{c}28.98^{\mathrm{a}} \pm 1.62 \\
(15)\end{array}$ & $\begin{array}{c}30.36^{\mathrm{a}} \pm 2.00 \\
(10)\end{array}$ \\
\hline M75 & $\begin{array}{c}25.85^{\mathrm{ns}} \pm 1.27 \\
(25)\end{array}$ & $\begin{array}{c}24.49^{\mathrm{ns}} \pm 1.65 \\
(12)\end{array}$ & - & - \\
\hline M75-1 & $\begin{array}{c}25.33^{\mathrm{ns}} \pm 0.91 \\
(88)\end{array}$ & $\begin{array}{c}26.61^{\mathrm{ns}} \pm 0.94 \\
(69)\end{array}$ & $\begin{array}{c}27.39^{\mathrm{ab}} \pm 1.06 \\
(44)\end{array}$ & $\begin{array}{c}25.75^{\mathrm{a}} \pm 1.24 \\
\text { (28) }\end{array}$ \\
\hline
\end{tabular}

For a particular parity (column), means that do not share any of the superscripts differ significantly $(\mathrm{P}<0.05)$. Breed group with sample size less than 10 have been excluded.

Values in the parenthesis give the sample size. 
Table 4. Additive genetic and heterotic effects of individual and maternal genotypes on reproductive traits based on the first four parities.

\begin{tabular}{ccccc}
\hline \multirow{2}{*}{ Traits } & $\begin{array}{c}\text { Individual } \\
\text { Additive Genetic } \\
\text { Effect }(\mathrm{a})\end{array}$ & $\begin{array}{c}\text { Maternal } \\
\text { Additive Genetic } \\
\text { Effect }(\mathrm{m})\end{array}$ & $\begin{array}{c}\text { Individual Heterosis } \\
\left(\mathrm{h}_{\mathrm{I}}\right)\end{array}$ & $\begin{array}{c}\text { Maternal } \\
\text { Heterosis } \\
\left(\mathrm{h}_{\mathrm{M}}\right)\end{array}$ \\
\hline GL (days) & $-5.51 \pm 4.81 \mathrm{~ns}$ & $11.74 \pm 9.61 \mathrm{~ns}$ & $11.59 \pm 9.82 \mathrm{~ns}$ & $-0.17 \pm 0.46 \mathrm{~ns}$ \\
CBW (kg) & $-4.02 \pm 2.96 \mathrm{~ns}$ & $8.95 \pm 6.21 \mathrm{~ns}$ & $10.64 \pm 6.46 \mathrm{~ns}$ & $0.74 \pm 0.41 \mathrm{~ns}$ \\
\hline
\end{tabular}

$\mathrm{GL}=$ Gestation length, $\mathrm{CBW}=$ Calve birth weight.

ns $=$ non-significant.

Table 5. Mean calve birth weight by sex, breed groups and calve death.

\begin{tabular}{llll}
\hline Breed group & \multicolumn{2}{c}{ Birth weight $(\mathrm{kg})$} & Calf death at birth (\%) \\
\hline M50 & Male $(\mathrm{kg})$ & Female $(\mathrm{kg})$ & \\
M50-1 & $27.44^{\mathrm{a}} \pm 0.70$ & $25.84^{\mathrm{b}} \pm 0.70$ & 4.56 \\
M50-2 & $27.25^{\mathrm{a}} \pm 0.73$ & $25.47^{\mathrm{b}} \pm 0.73$ & 3.49 \\
M50-3 & $27.22^{\mathrm{a}} \pm 0.73$ & $24.75^{\mathrm{bc}} \pm 0.73$ & 4.28 \\
M56 & $26.98^{\mathrm{a}} \pm 0.83$ & $24.96^{\mathrm{bc}} \pm 0.85$ & 6.80 \\
M63 & $24.57^{\mathrm{bc}} \pm 0.84$ & $22.89^{\mathrm{c}} \pm 0.82$ & 4.90 \\
M75 & $27.99^{\mathrm{a}} \pm 1.22$ & $27.49^{\mathrm{a}} \pm 1.23$ & 3.72 \\
M75-1 & $26.14^{\mathrm{a}} \pm 1.67$ & $23.54^{\mathrm{bc}} \pm 1.71$ & 7.27 \\
Overall & $27.84^{\mathrm{a}} \pm 0.87$ & $24.70^{\mathrm{bc}} \pm 0.87$ & 5.66 \\
\hline
\end{tabular}

Means for particular parameter (row) that do not share any superscripts are significantly different $(\mathrm{P}<0.05)$.

Taneja et al. (1980) and Sivarajasingam and Kumar (1983, 1986) reported that breed group and parity had highly significant effects on CBW. Roy et al. (2007) also reported breed group has a significant effect on CBW. In the present study there were no significant differences in CBW among M50, M50-1, M63 and M75-1 breed groups. Shamsuddin et al. (1998) observed lower CBW in $50 \%$ and $75 \%$ Friesian inheritance in Malaysia (20.99 \pm 7.57 and $24.20 \pm 6.44 \mathrm{~kg}$, respectively) which may be due to different farm and management practices. CBW was the lowest in first parity and gradually increased to the third parity which may be due to the increased age of the dam resulting in increased body weight, and therefore, also in higher birth weight of the calves. Similar trend was also reported in the other herds of Friesian $\times$ Sahiwal crossbred calves (Sakhare and Ingle, 1983 and Bhat et al., 1978).
Calf sex significantly $(\mathrm{P}<0.01)$ affected the CBW in all breed groups, except M56 and M63. Male calves were significantly $(\mathrm{P}<0.01)$ heavier than the females. The differences in birth weight between calves of the two sexes were due to the fact that male foetus grows faster during prenatal development. This may be ascribed to the anabolic effect of the sex hormone, testosterone, secreted by the gonads this stage of life (Hafez, 1987). Koul et al. (1980) and Sadana and Basu (1981) and Sakhare and Ingle (1983) observed calf sex to have a significant $(\mathrm{P}<0.01)$ effect on CBW in $25-75 \%$ Friesian inheritance. Male calves heavier than female calves was also found by Koul et al. (1980) in crossbred calves, Dev and Talukder (2006) in local calves and Sivarajasingam and Kummar $(1983,1986)$ in 25 - 75\% Friesian inheritance. 
Calf mortality ranged between $3.49-7.27 \%$. The highest calf mortality at birth was observed in M75 (7.27\%), followed by M50-3 (6.80\%) and M75-1 (5.66\%). The lowest mortality was found in M50-1 (3.49\%). Higher calf mortality M75 and M75-1 may be due to higher percentage of Friesian genes in the animals which may have contributed to adaptation problems in the tropical environment. The small sample size in M75 may also contribute to some error in the estimation. Lower calf mortality of M50-1 may be because this group had better adaptation than other breed groups. This may be due to the high heterozygosity in its genome. M50-3 resulting from inter se mating of M50 did not have such low mortality which may be due to the effect of selection for higher milk yield indirectly selecting for higher Friesian genes in the genome and therefore, loss of heterozigosity. The average calf mortality in the present study was $4.5 \%$. Similar calf mortality $(4-5 \%)$ was found by Sofian (1996) in five dairy herds in Malaysia. The non genetic factors year of birth only affected GL, but most of the genetic factors like sire breed group, parity, calf sex, breed group $\times$ parity and non genetic factors like year of birth and age at calving significantly $(\mathrm{P}<0.05)$ affected calf birth weight.

\section{References}

Bhat, P. N., Taneja, V. K., and Garg, R. C. 1978. Body weight changes in Holstein $\mathrm{x}$ Sahiwal cross-breds in relation to level of Holstein inheritance. Indian Journal of Animal Science, 48(7): 485-491.

Bourdon, R. M. and Brinks, J. S. 1982. Genetic, environmental and phenotypic relationship among gestation length, birth weight, growth traits and age at first calving in beef cattle. Journal of Animal Science, 55: 543

Chew, L. C., Maier, J. K, Hillers and Hodgson, A. S., 1981. Relationship between calf birth weight and dams subsequent 200 and 305 day yields of milk fat and total solids in Holsteins. Journal of Dairy Science, 64: 2401.
Dev. G.K. and Talukder, M.A.I. 2006 Genetic evaluation of Native cattle for birth weight. Bangladesh Journal of Livestock Research. Vol. 13 (1 \&2):39-45.

DVS (Department of Veterinary Services). 1998. Livestock production and per capita consumption of livestock products. Malaysia. pp 41- 49.

Singh, G., Chhillar, R. S., Patil, R. R., Prasad. M. and Prasad. R. 1980. Note on the performance of cross bred (Friesian $\times$ Sahiwal) cows at the Indian Agricultural Research Institute, New Delhi. Indian Journal of Animal Science, 50(12): 11261128.

Hafez, E. S. E. 1987. Reproduction in farm Animals $\left(6^{\text {th }}\right.$ edition) Lea and Febiger, Philadelphia, USA. p. 102.

Islam, S. S. and Bhuiyan, A. K. F. H. 1997. Performance of crossbred Sahiwal cattle at the Pabna milk shed area in Bangladesh. Asian-Australasian Journal of Animal Science, 10 (6): 581-586.

Koul, G. L., Srivastava, B.B., Singhal, R. A., Kaushik, S.N. and Katpatal, B. G. 1980. Genetic and environmental factors affecting the birth weight of second generation of crossbred calves. Indian Journal of Animal Science, 50(11): 923-927.

Leibholz, J. 1973. Correlations between birth weight, weaning weights, 11-week weights, weight gains and feed conversion ratios of early weaned calves. Australian Journal of Experimental Agriculture and Animal Husbandry, 13: 483.

Majid, M. A., Talukder, A. I and Zahiruddin, M. 1996. Productive performance of pure breeds, $\mathrm{F} 1, \mathrm{~F} 2$, and F3 generations cows raised in central cattle breeding and dairy farm of Bangladesh. Asian Australasian Journal of Animal Science, 9 (4): 461-464.

Osman. A. 1993. Dairy Production. Animal Industry in Malaysia, Faculty of Veterinary Medecine \& Animal Sciences, Universiti Pertanian Malaysia, Serdang: pp 41 - 49 
Rajan, M. R., Parekh, H. K.B. and Dave, B. K. 1981. Effect of genetic and non genetic factors on reproductive traits in half breeds. Indian Journal of Animal Science, 51(12): 1224-1227.

Randel, R. D. 1990. Proceeding 39th Annual Beef Cattle short course, University of Florida, pp 60 .

Roy, R., Tomar, S.P.S., Manglik, V.P., Sharma, R.J. and Chaudhary, R. P. 1985. Factors affecting reproductive and productive traits in different crossbred dairy cattle. Indian Journal of Animal Science, 55 (5): 385-386.

Roy, B K., Wadud, A., Islam, M.N., Roy, A., Bhuiyan, M.S.A. and Faruque. S. 2007. Quantitative analysis on productive and reproductive performances of different groups of dairy cows in two military dairy farms. Bangladesh Journal of Livestock Research, 14 (1 \&2):136-145.

Sakhare, P.G. and Ingle, U.M. 1983. Genetic and non genetic factors affecting birth weight in Holstein- Friesian $\times$ Sahiwal crossbred calves. Indian Journal of Dairy Science, 36 (2): 184-186.

Shamsudin, A B., Ariff, O. M., Azahar, I., and Anthony, A. 1998. Growth performance of crossbred Friesian calves from birth to one year old. Proceeding $20^{\text {th }}$ Malaysian society of Animal Production Conference 27-28 July Putra Jaya, Malaysia. pp. 141142.

Sivarajasingam, S. and Mukherjee, T. K., 1982. Genetic, phenotypic and environmental correlation co-efficients between milk yield and other economic traits. Malaysian Agriculture Journal, 52: 257.

Sivarajasingam, S., Yusoff. S., Mohamad N., Sivasupramaniam, G., Abas, M. O. and Eusof, J. 1982. Dairy cattle Production in Peninsular Malaysia. Proceeding . Conference. Malaysian Livestock Industries; Status and Potential, Genting Highlands, Malaysia, pp. 37 - 87.
Sivarajasingam, S. and Kumar, A. K. 1983. Level of Holstein - Friesian inheritance on calf birth weight. Proceeding 7th Annual Conference Malaysian Association of Animal Production pp. 133-137.

Sivarajasingam, S. and Kumar, A. K 1986. Genetic and some environmental factors affecting birth weight of zebu, Friesian and Jersey purebred and crossbred calves. Malaysian Agricultural Research Development Institute Research Bulletin 14(1):63-68

Sivarajasingam, S. and Kumar, A. R. 1993. Comparative performance of Malaysian, Australian and New Zealand F1 Friesian crossbreds. Livestock Production Science, 36: 299-310.

Sadana, D. K. and Basu, S. B. 1981. Production performance of exotic breeds in India. Indian Journal of Dairy Science, 34 (4): 443-447.

Sofian, J., 1996. Production and reproduction performance of dairy cows in five large Government herds in Malaysia. A thesis Master of Science presented to the Faculty of Graduate Studies of the University of Guelph.

Taneja, V. K., Basu, D.S., Bhatnagar, D. S. and Rao, V. P. 1980. Genetic and non genetic factors affecting body weights in Brown Swiss $\mathrm{x}$ Sahiwal crosses. Indian Journal of Dairy Science, 33(3): 341-346.

Vale-Filho, VR Pinheiro LE and Basrur PK 1986. In Current Therapy in Theriogenology, saunders, Philadelphia, pp 43 